\title{
Pengaruh Jenis Ikan Air Tawar Berbeda Terhadap Karakteristik Mutu Kerupuk Amplang Ikan
}

\section{The Effect of Different Types of Freshwater Fish on the Quality Characteristics of Amplang Fish Crackers}

\author{
Widya Amirah Maisur'1a, Desmelati' ${ }^{1}$ Dewita $^{2}$
}

1Jurusan Teknologi Hasil Perikanan Fakultas Perikanan Dan Kelautan Universitas Riau Kampus Bina Widya, Km. 12,5 Simpang Baru, Pekanbaru 28293.

aKorespondensi: Desmelati, E-mail: desmelati16@gmail.com

(Diterima oleh Dewan Redaksi: 10 - 06 - 2019)

(Dipublikasikan oleh Dewan Redaksi: 30 - 10 - 2019)

\begin{abstract}
This study aimed to determine the effect of different types of freshwater fish on the quality characteristics of Amplang fish crackers produced. The method used in this study was the experimental method, which was processing the amplang fish crackers using different types of freshwater fish (pangas catfish, catfish and snakehead fish). The design used in this study was a non-factorial Completely Randomized Design (RAL), with 3 different types of freshwater fish treatment namely amplang crackers with the addition of pangas catfish meat (A1), amplang crackers with addition catfish meat (A2), amplang crackers with addition snakehead catfish meat (A3). The parameters tested in this study were the organoleptic test, proximate analysis and volume of development. The results showed that the use of different types of freshwater fish had a significant effect on organoleptic values, proximate analysis and volume development tests at a 95\% confidence level. The crackers with addition snakehead catfish meat (A3) was the best treatment with the organoleptic value of appearance (8.60), flavor (7.29), texture (8.31) and taste (7.32). While for the proximate value of water content $(1.69 \%)$, ash content $(3.45 \%)$, protein content $(27.97 \%)$, fat content $(15.49 \%)$ and development volume test value (462.82\%), and overall products meet SNI standards.
\end{abstract}

Keywords: amplang crackers, type of freshwater fish, quality characteristic

\begin{abstract}
ABSTRAK
Penelitian ini bertujuan untuk mengetahui pengaruh jenis ikan air tawar berbeda terhadap karakteristik mutu kerupuk amplang ikan yang dihasilkan. Metode yang digunakan dalam penelitian ini adalah metode eksperimen, yaitu melakukan pengolahan kerupuk amplang menggunakan jenis ikan air tawar berbeda (ikan patin, ikan lele dan ikan gabus). Rancangan yang digunakan dalam penelitian ini adalah Rancangan Acak Lengkap (RAL) non faktorial, dengan 3 perlakuan jenis ikan air tawar berbeda yaitu kerupuk amplang dengan penggunaan daging ikan patin $\left(\mathrm{A}_{1}\right)$, kerupuk amplang dengan penggunaan daging ikan lele $\left(\mathrm{A}_{2}\right)$, kerupuk amplang dengan penggunaan daging ikan gabus $\left(A_{3}\right)$. Parameter yang diuji dalam penelitian ini adalah uji organoleptik, analisis proksimat dan volume pengembangan. Hasil penelitian menunjukkan bahwa penggunaan jenis ikan air tawar berbeda memberikan pengaruh yang nyata terhadap nilai organoleptik, analisis proksimat dan uji volume pengembangan pada tingkat kepercayaan 95\%. Perlakuan yang terbaik yaitu jenis ikan gabus $\left(\mathrm{A}_{3}\right)$ dengan presentasi nilai organoleptik rupa $(8,60)$, aroma $(7,29)$, tekstur $(8,31)$ dan rasa $(7,32)$. Sementara untuk nilai proksimat kadar air (1,69\%), kadar abu $(3,45 \%)$, kadar protein $(27,97 \%)$, kadar lemak $(15,49 \%)$ dan nilai uji volume pengembangan $(462,82 \%)$, serta secara keseluruhan produk memenuhi standar SNI.
\end{abstract}

Kata kunci: amplang, karakteristik, jenis ikan air tawar

Maisur, Widya Amirah, Desmelati, Dewita. 2019. Pengaruh Jenis Ikan Air Tawar Berbeda Terhadap Karakteristik Mutu Kerupuk Amplang Ikan. Jurnal Agroindustri Halal 5(2): 151 - 160. 


\section{PENDAHULUAN}

Kerupuk merupakan suatu jenis makanan ringan yang sudah lama dikenal oleh sebagian besar masyarakat Indonesia. Asal mula kerupuk masih kurang jelas, karena kerupuk tidak hanya dikenal dan dikonsumsi oleh masyarakat Indonesia, tetapi juga di Negara-negara Asia lainnya, seperti Malaysia, Singapur dan Cina.

Bahan yang digunakan dalam pembuatan kerupuk meliputi bahan baku utama, yaitu bahan yang digunakan dalam jumlah besar dan bahan tambahan yang merupakan bahan pelengkap bahan baku utama dalam proses produksi. Bahan baku yang digunakan harus mengandung pati cukup tinggi sehingga mengalami pengembangan volume selama penggorengan, misalnya tepung tapioka, tepung sagu, tepung terigu atau tepung beras. Bahan baku hewani seperti udang dan ikan juga sering digunakan dalam pembuatan kerupuk. Hal ini bertujuan untuk menambah cita rasa dalam olahan kerupuk. Salah satu kerupuk yang menggunakan bahan baku hewani yaitu kerupuk amplang.

Kerupuk amplang merupakan olahan hasil perikanan yang melalui proses penggorengan, bentuk panjang atau lonjong, serta memiliki cita rasa yang gurih dan enak. Kerupuk amplang sangat mudah ditemukan di daerah Kalimantan Timur, karena kerupuk amplang tersebut merupakan makanan khas daerah tersebut. Tetapi, kerupuk amplang juga ditemukan di daerah Kabupaten Indragiri Hilir dan biasa juga dijadikan oleholeh khas daerah tersebut. Produk dari kedua daerah memiliki nama yang sama tetapi berbeda bahan baku hewani, dimana kerupuk amplang yang ada di Kalimantan Timur menggunakan ikan tenggiri sedangkan kerupuk amplang yang ada di Kabupaten Indragiri Hilir menggunakan udang sungai atau udang tenggek yang biasa disebut masyarakat sekitar.

Persaingan industri kerupuk amplang sangat tinggi, sementara jumlah pasokan perikanan terutama di daerah Riau semakin meningkat. Sejauh ini hanya ada pengolahan kerupuk amplang ikan tenggiri dan udang tenggek yang popular di masyarakat, padahal jika dilihat dari segi bahan yang tersedia dipasaran terutama ikan air tawar, belum ada produksi kerupuk amplang ikan patin, lele dan gabus. Sehingga penganekaragaman produk kerupuk amplang sangat mungkin dilakukan dengan menggunakan bahan tambahan hewani dari daging ikan patin, ikan lele dan ikan gabus.

Bahan baku hewani yang digunakan dalam pengolahan kerupuk amplang dapat mempengaruhi hasil akhir dalam pembuatan kerupuk amplang. Menurut Wiranti (2015) bahan tambahan hewani yang memiliki daging kemerahan dapat menghasilkan warna lebih kecoklatan pada kerupuk ketika telah digoreng, sebaliknya daging yang berwarna putih menghasilkan warna kerupuk yang lebih putih, selain itu kandungan protein dan lemak dalam bahan hewani juga dapat mempengaruhi rasa, aroma dan kehalusan permukaan kerupuk.

Sejauh ini belum banyak dilakukan penelitian tentang pengaruh jenis ikan berbeda terhadap karakteristik mutu kerupuk amplang ikan, terutama karakteristik mutu kerupuk amplang ikan air tawar yaitu ikan patin, lele dan gabus. Berdasarkan pemikiran tersebut penulis tertarik melakukan penelitian mengenai pengaruh jenis ikan air tawar berbeda terhadap karakteristik mutu kerupuk amplang ikan, yang diharapkan mampu memberikan informasi karakteristik kerupuk amplang ikan air tawar berbeda dan variasi baru terhadap produk hasil perikanan. Penelitian ini bertujuan untuk mengetahui pengaruh jenis ikan air tawar berbeda terhadap karakteristik mutu kerupuk amplang ikan yang dihasilkan.

\section{METODE PENELITIAN}

\section{Bahan dan alat}

Bahan yang digunakan dalam pengolahan kerupuk amplang adalah daging ikan patin, ikan lele dan ikan gabus yang diperoleh dari pasar selasa, Panam, Pekanbaru, masing-masing ikan sebanyak 4 $\mathrm{kg}$, tepung tapioka, bawang putih, garam dan minyak goreng. Serta bahan yang digunakan 
untuk analisis kimia yaitu aquades, $\mathrm{H}_{2} \mathrm{SO}_{4}$, $\mathrm{NaOH} 50 \%, \mathrm{HCl}, \mathrm{H}_{2} \mathrm{BO}_{3}, \mathrm{Cu}$ kompleks, indikator campuran (metil etilen merahbiru), indikator pp dan bahan kimia lainnya.

Peralatan yang digunakan dalam pembuatan amplang ikan air tawar berbeda yaitu timbangan, baskom sedang, sendok makan, pisau, blender, spatula, talenan, wajan, sendok penggoreng, kompor dan kertas roti. Selain itu alat laboratorium yang digunakan untuk analisis kimia yaitu oven, desikator, timbangan, cawan porselin, erlemeyer, gelas ukur, tanur listrik, labu lemak, sokhlet, labu kjedahl, lemari asam, alat destilasi, alat titrasi, tabung reaksi dan beaker glass.

\section{Metode Penelitian}

Metode yang digunakan adalah metode eksperimen, yaitu melakukan pengolahan kerupuk amplang menggunakan jenis ikan air tawar berbeda yaitu ikan patin, lele dan gabus secara langsung. Rancangan yang digunakan adalah Rancangan Acak Lengkap (RAL) non faktorial, dengan perlakuan jenis daging ikan berbeda, setiap perlakuan diulang sebanyak tiga kali, sehingga satuan percobaan pada penelitian ini yaitu 9 unit percobaan.

\section{Kerupuk Amplang (SNI 7762:2013)}

Persyaratan mutu dan keamanan pangan amplang ikan sesuai dalam SNI 7762:2013 yaitu dapat dilihat pada Tabel 1.

Tabel 1. SNI Amplang ikan

\begin{tabular}{lc}
\hline \multicolumn{1}{c}{ Parameter uji } & Persyaratan \\
\hline Sensori & Min 7 ( skor $1-9)$ \\
Kadar air & Maks 4,0\% \\
Kadar abu & Maks 5,0\% \\
Kadar lemak & Maks 35,0\% \\
Kadar protein & Min 7,0 \% \\
\hline
\end{tabular}

\section{Prosedur Penelitian}

a. Formulasi Kerupuk Amplang Ikan

Formulasi kerupuk amplang ikan yang digunakan dalam pembuatan kerupuk amplang ikan dengan menggunakan daging ikan air tawar berbeda dapat dilihat pada Tabel 2.

Tabel 2. Formulasi kerupuk amplang ikan dengan penggunaan jenis ikan air tawar berbeda (Rabiyatul 2016) yang dimodifikasi.

\begin{tabular}{lccc}
\hline \multirow{2}{*}{ Formulasi } & \multicolumn{3}{c}{ Jenis daging ikan } \\
\cline { 2 - 4 } & Ikan patin $\left(\mathrm{A}_{1}\right)$ & Ikan lele $\left(\mathrm{A}_{2}\right)$ & Ikan gabus $\left(\mathrm{A}_{3}\right)$ \\
\hline Daging ikan $(\mathrm{g})$ & 450 & 450 & 450 \\
Tepung tapioka $(\mathrm{g})$ & 225 & 225 & 225 \\
Bawang putih $(\mathrm{g})$ & 9 & 9 & 9 \\
Garam $(\mathrm{g})$ & 9 & 9 & 9 \\
Air (ml) & 150 & 150 & 150 \\
\hline
\end{tabular}

b. Prosedur Pembuatan Kerupuk Amplang Ikan

Pertama dilakukan penyiangan pada ikan patin, lele dan gabus, dengan cara membuang isi perut, insang, kepala, sirip, dan sisik pada ikan gabus dan dicuci bersih dengan menggunakan air mengalir. Kemudian ikan di fillet dan dipisahkan dari kulit dan tulangnya lalu dipotong kacil-kecil.
Daging yang telah dipotong lalu ditimbang kemudian dihaluskan dengan menggunakan blender dengan menambahkan $150 \mathrm{ml}$ air. Mixer semua bahan selama 10 menit. Adonan yang telah homogen kemudian dibentuk memanjang dan dipotong kurang lebih $1 \mathrm{~cm}$, kemudian adonan digoreng dengan menggunakan minyak panas selama 25 menit. 


\section{HASIL DAN PEMBAHASAN}

\section{Proksimat Daging Ikan Segar}

Analisis proksimat pada suatu bahan pangan dilakukan untuk mengetahui kandungan gizi yang terkandung didalamnya.
Analisis proksimat daging segar ikan patin, lele dan gabus meliputi analisis kadar air, kadar abu, kadar protein, kadar lemak dan kadar karbohidrat (by different). Hasil analisis proksimat daging segar ikan patin, lele dan gabus dapat dilihat pada Tabel 3 .

Tabel 3. Hasil analisis proksimat daging segar ikan patin, lele dan gabus.

\begin{tabular}{lccc}
\hline Proksimat & Patin (\%bb) & Lele (\%bb) & Gabus (\%bb) \\
\hline Kadar air & 81,45 & 79,27 & 79,54 \\
Kadar abu & 0,71 & 1,08 & 0,98 \\
Kadar lemak & 1,90 & 0,89 & 0,22 \\
Kadar protein & 15,32 & 17,92 & 18,99 \\
Karbohidrat & 0,61 & 0,83 & 0,26 \\
\hline
\end{tabular}

\section{Nilai Organoleptik}

Penilaian organoleptik dilakukan oleh 25 orang panelis agak terlatih dengan menggunakan score sheet yang telah disediakan. Panelis diminta untuk memberikan tanggapan terhadap kerupuk amplang ikan dengan penggunaan jenis ikan air tawar berbeda dengan memberikan tanggapan berupa nilai dengan 4 parameter yaitu rupa, aroma, tekstur dan rasa. Nilai rata-rata uji organoleptik kerupuk amplang ikan dapat dilihat pada Tabel 4.

Tabel 4. Nilai rata-rata uji organoleptik kerupuk amplang ikan dengan penggunaan jenis ikan air tawar berbeda.

\begin{tabular}{lccc}
\hline \multirow{2}{*}{ Organoleptik } & \multicolumn{3}{c}{ Perlakuan } \\
\cline { 2 - 4 } & $\mathrm{A}_{1}$ & $\mathrm{~A}_{2}$ & $\mathrm{~A}_{3}$ \\
\hline Rupa & $5,77^{\mathrm{a}} \pm 0,09$ & $6,97^{\mathrm{b}} \pm 0,88$ & $8,60^{\mathrm{c}} \pm 0,4$ \\
Troma & $6,89^{\mathrm{a}} \pm 0,05$ & $7,00^{\mathrm{a}} \pm 0,89$ & $7,29^{\mathrm{a}} \pm 0,20$ \\
Tekstur & $6,15^{\mathrm{a}} \pm 0,20$ & $7,85^{\mathrm{b}} \pm 0,32$ & $8,31^{\mathrm{b}} \pm 0,12$ \\
Rasa & $6,87^{\mathrm{a}} \pm 0,67$ & $7,35^{\mathrm{a}} \pm 0,84$ & $7,32^{\mathrm{a}} \pm 0,21$ \\
\hline - Angka-angka yang diikuti huruf yang sama berarti tidak berbeda nyata pada tingkat kepercayaan $95 \%$. &
\end{tabular}

\section{Rupa}

Berdasarkan Tabel 4 diketahui bahwa nilai rata-rata rupa kerupuk amplang ikan dengan penggunaan jenis ikan air tawar berbeda berturut-turut 5,77, 6,97 dan 8,60. Dimana perlakuan $\mathrm{A} 3$ memiliki nilai tertinggi $(8,60)$ dengan ciri-ciri amplang ikan yang berwarna cerah merata spesifik produk, bersih, sedangkan perlakuan $\mathrm{A}_{1}$ memiliki nilai terendah $(5,77)$ dengan ciri-ciri warna kusam, kurang bersih.

Hasil dari analisis variansi didapat bahwa perlakuan dengan penggunaan jenis ikan air tawar berbeda berpengaruh nyata terhadap nilai rupa kerupuk amplang ikan, dimana $F_{\text {Hitung }}(666,57)>F_{\text {Tabel }}(5,14)$ pada tingkat kepercayaan 95\% maka hipotesis $\left(\mathrm{H}_{0}\right)$ ditolak.

Berdasarkan hasil uji lanjut beda nyata terkecil (BNT) menunjukkan bahwa perlakuan $\mathrm{A}_{3}$ berbeda nyata terhadap perlakuan $A_{2}$, dan perlakuan $A_{2}$ berbeda nyata terhadap perlakuan $\mathrm{A}_{1}$ pada tingkat kepercayaan 95\%. Hasil penelitian diketahui bahwa nilai rupa kerupuk amplang dengan penggunaan jenis ikan air tawar berbeda yang terbaik adalah dengan penggunaan jenis ikan gabus $\left(\mathrm{A}_{3}\right)$ karna menghasilkan 
berwarna kerupuk amplang yang cerah merata spesifik produk dan bersih sehingga disukai oleh panelis.

Rupa kerupuk amplang ikan yang berwarna cerah (putih kekuningan) atau kusam kecoklatan disebabkan oleh bahan baku yang digunakan. Menurut Nofitasari (2015) warna daging yang lebih merah mendominasi warna produk lebih gelap. Pigmen warna daging ikan juga dipengaruhi oleh sumsum tulang dan otot yang terdapat pada daging. Sumsum tulang kaya akan hemoglobin dan otot kaya akan mioglobin. Keduanya berkontribusi terhadap warna merah daging. Jika mengalami proses pemanasan (penggorengan) akan terjadi denaturasi globin. Hasil denaturasi tersebut jika teroksidasi akan menghasilkan warna coklat sedangkan daging putih yang memiliki kandungan mioglobin rendah mengakibatkan warna produk makin terang.

Ikan gabus memiliki daging berwarna putih kemerahan, sedangkan daging ikan patin dan ikan lele berwarna merah kekuningan. Menurut Suwarsito (2007), Warna kekuningan pada daging ikan disebabkan oleh kadar lemak daging yang tinggi.

\section{Aroma}

Berdasarkan Tabel 4 diketahui nilai rata-rata aroma kerupuk amplang ikan dengan penggunaan jenis ikan air tawar berbeda berturut-turut 6,89, 7,00 dan 7,29. Dimana perlakuan $A_{1}, A_{2}$, dan $A_{3}$ memiliki ciri-ciri aroma kerupuk amplang ikan yaitu aroma cukup kuat spesifik produk. Hasil dari analisis variansi didapat bahwa perlakuan dengan penggunaan jenis ikan air tawar berbeda berpengaruh nyata terhadap nilai aroma kerupuk amplang ikan, dimana $F_{H i t u n g}$ $(2142,96)>F_{\text {Tabel }}(5,14)$ pada tingkat kepercayaan $95 \%$ maka hipotesis $\left(\mathrm{H}_{0}\right)$ ditolak.

Berdasarkan hasil uji lanjut beda nyata jujur (BNJ) menunjukkan bahwa perlakuan $\mathrm{A}_{3}$ tidak berbeda nyata terhadap perlakuan $\mathrm{A}_{2}$ dan $\mathrm{A}_{1}$ pada tingkat kepercayaan 95\%. Hasil penelitian diketahui bahwa nilai aroma kerupuk amplang ikan dengan penggunaan jenis ikan air tawar berbeda memiliki nilai yang tidak jauh berbeda pada setiap perlakuan, dimana setiap perlakuan kerupuk amplang ikan beraroma cukup kuat spesifik produk.

Menurut penelitian Laiya et al. (2014) yang menyatakan bahwa konsentrasi tepung sagu yang rendah dibandingkan ikan gabus (30:70) menghasilkan aroma yang lebih disukai panelis. Adanya aroma khas kerupuk ikan gabus diduga disebabkan oleh kandungan protein yang terurai menjadi asam amino khususnya asam glutamat yang akan menimbulkan rasa dan aroma yang lezat. Hal ini juga sejalan dengan penelitian Suseno et al. (2004) yang melaporkan bahwa penambahan daging ikan nilem (Ostheochilus hasselti) pada pembuatan kerupuk yang disubtitusi dengan tepung tapioka, peningkatan aroma berasal dari ikan yang digunakan. Konsentarasi daging ikan nilem yang ditambahkan dapat menyebabkan kerupuk mempunyai aroma khas kerupuk ikan.

\section{Tekstur}

Berdasarkan Tabel 4 diketahui bahwa nilai rata-rata teksur kerupuk amplang ikan dengan penggunaan jenis ikan air tawar berbeda berturut-turut 6,15, 7,85 dan 8,31. Dimana perlakuan $\mathrm{A}_{3}$ memiliki nilai tertinggi $(8,31)$ dengan ciri-ciri amplang ikan yang bertekstur renyah dan berongga, sedangkan perlakuan $A_{1}$ memiliki nilai terendah $(6,15)$ dengan ciri-ciri renyah dan padat.

Hasil dari analisis variansi didapat bahwa perlakuan dengan penggunaan jenis ikan air tawar berbeda berpengaruh nyata terhadap nilai tekstur kerupuk amplang ikan, dimana $\mathrm{F}_{\text {Hitung }}(4219,53)>\mathrm{F}_{\text {Tabel }}(5,14)$ pada tingkat kepercayaan 95\% maka hipotesis $\left(\mathrm{H}_{0}\right)$ ditolak.

Berdasarkan hasil uji lanjut beda nyata jujur (BNJ) menunjukkan bahwa perlakuan $\mathrm{A}_{3}$ tidak berbeda nyata terhadap perlakuan $A_{2}$, tetapi perlakuan $A_{3}$ dan $A_{2}$ berbeda nyata terhadap perlakuan $\mathrm{A}_{1}$ pada tingkat kepercayaan 95\%. Hasil penelitian diketahui bahwa nilai tekstur kerupuk amplang ikan dengan penggunaan jenis ikan air tawar berbeda yang terbaik adalah dengan penggunaan jenis ikan gabus $\left(\mathrm{A}_{3}\right)$ dimana 
nilai rata-rata tekstur tertinggi yaitu 8,16 karena memiliki tekstur kerupuk amplang ikan yang renyah dan berongga sehingga lebih disukai oleh panelis.

Menurut Haryadi (1990) dalam Alfisyahrica (2015), menyatakan bahwa kerenyahan kerupuk sangat dipengaruhi oleh besarnya pengembangan kerupuk pada waktu digoreng. Hal ini dijelaskan bahwa kerupuk pada saat digoreng akan membentuk rongga-rongga didalamnya. Semakin banyak rongga-rongga yang terbentuk akan semakin renggang strukturnya, sehingga mudah dipatahkan. Dengan demikian semakin tinggi daya kembangnya maka akan semakin tinggi pula kerenyahanya.

\section{Rasa}

Berdasarkan Tabel 4 diketahui nilai rata-rata rasa kerupuk amplang ikan dengan penggunaan jenis ikan air tawar berbeda yaitu berturut-turut 6,87, 7,35 dan 7,32. Dimana perlakuan $A_{1}, A_{2}$, dan $A_{3}$ mamiliki ciri-ciri rasa kerupuk amplang ikan yaitu rasa cukup kuat spesifik ikan. Hasil dari analisis variansi didapat bahwa perlakuan dengan penggunaan jenis ikan air tawar berbeda berpengaruh nyata terhadap nilai rasa kerupuk amplang ikan, dimana FHitung $(518,05)>F_{\text {Tabel }}(5,14)$ pada tingkat kepercayaan 95\% maka hipotesis $\left(\mathrm{H}_{0}\right)$ ditolak.

Berdasarkan hasil uji lanjut beda nyata terkecil (BNT) menunjukkan bahwa perlakuan $\mathrm{A}_{3}$ tidak berbeda nyata terhadap perlakuan $\mathrm{A}_{2}$ dan $\mathrm{A}_{1}$ pada tingkat kepercayaan 95\%. Hasil penelitian diketahui bahwa nilai rasa kerupuk amplang ikan dengan penggunaan jenis ikan air tawar berbeda memiliki nilai yang tidak jauh berbeda, dimana kerupuk amplang ikan memiliki rasa cukup kuat spesifik ikan. Hal ini karena perbandingan jumlah daging ikan dan bumbu-bumbu yang digunakan sama di setiap perlakuan, sehingga memberikan rasa cukup kuat spesifik ikan dan rasa yang hampir sama.

Laiya et al. (2014) mengatakan bahwa pada produk perikanan, rasa gurih disebabkan oleh senyawa yang terdapat pada ikan yaitu asam amino, pembentuk cita rasa seperti glisin, alanin, lisin serta asam glutamat.

\section{Proksimat Kerupuk Amplang}

Nilai rata-rata analisis proksimat pada kerupuk amplang ikan denga penggunaan jenis ikan air tawar berbeda dapat dilihat pada Tabel 5 .

Tabel 5. Nilai rata-rata proksimat (\%) kerupuk amplang ikan dengan penggunaan jenis ikan air tawar berbeda.

\begin{tabular}{lccc}
\hline \multirow{2}{*}{ Proksimat } & \multicolumn{3}{c}{ Perlakuan } \\
\cline { 2 - 4 } & $\mathrm{A}_{1}$ & $\mathrm{~A} 2$ & $\mathrm{~A} 3$ \\
\hline Kadar air & $2,43^{\mathrm{b}} \pm 0,96^{\mathrm{b}}$ & $1,52^{\mathrm{a}} \pm 0,90 \mathrm{a}$ & $1,69^{\mathrm{a}} \pm 1,25^{\mathrm{a}}$ \\
Kadar abu & $3,10^{\mathrm{a}} \pm 0,00$ & $3,97^{\mathrm{b}} \pm 0,00$ & $3,45^{\mathrm{a}} \pm 0,05$ \\
Kadar protein & $17,25^{\mathrm{a}} \pm 0,27^{\mathrm{a}}$ & $20,53^{\mathrm{b}} \pm 0,48 \mathrm{~b}$ & $27,97^{\mathrm{c}} \pm 0,05^{\mathrm{b}}$ \\
Kadar lemak & $24,32^{\mathrm{c}} \pm 0,01$ & $19,72^{\mathrm{b}} \pm 0,02$ & $15,49^{\mathrm{a}} \pm 0,05$ \\
\hline
\end{tabular}

Keterangan: Angka-angka yang diikuti huruf yang sama berarti tidak berbeda nyata pada tingkat kepercayaan 95\%. $A_{1}=$ amplang ikan patin, $A_{2}=$ amplang ikan lele, $A_{3}=$ amplang ikan gabus

\section{Kadar air}

Berdasarkan Tabel 5 diketahui bahwa nilai rata-rata kadar air kerupuk amplang ikan dengan penggunaan jenis ikan air tawar berbeda berturut-turut 2,46\%, 1,52\% dan 1,69\%. Dimana perlakuan A2 memiliki nilai terendah $(1,52 \%)$ sedangkan perlakuan $\mathrm{A}_{1}$ memiliki nilai tertinggi $(2,46 \%)$. Hasil dari analisis variansi didapat bahwa perlakuan dengan penggunaan jenis ikan air tawar berbeda berpengaruh nyata terhadap nilai kadar air kerupuk amplang ikan, dimana $\mathrm{F}_{\text {Hitung }}(147,75)>\mathrm{F}_{\text {Tabel }}(5,14)$ pada tingkat kepercayaan 95\% maka hipotesis $\left(\mathrm{H}_{0}\right)$ ditolak. 
Berdasarkan hasil uji lanjut beda nyata terkecil (BNT) menunjukkan bahwa perlakuan $\mathrm{A}_{3}$ tidak berbeda nyata terhadap perlakuan $A_{2}$, tetapi perlakuan $A_{3}$ dan $A_{2}$ berbeda nyata terhadap perlakuan $\mathrm{A}_{1}$ pada tingkat kepercayaan 95\%. Kadar air pada kerupuk dipengaruhi oleh kadar air dari bahan baku yang digunakan. Bahan baku kerupuk yang mengandung kadar air tinggi akan menghasilkan kerupuk yang mengandung kadar air yang tinggi pula, begitu pula sebaliknya. Menurut Dewita dan Syahrul (2014) kadar air merupukan parameter mutu yang sangat penting bagi suatu produk makanan, semakin rendah kadar air produk, maka semakin tinggi daya tahan produk.

Kadar air yang dihasilkan kerupuk amplang ikan dengan penggunaan jenis ikan air tawar berbeda masih berada dibawah persyaratan SNI (maks 4\%) sehingga dapat dikatakan bahwa kadar air kerupuk amplang ikan dengan penggunaan jenis ikan air tawar berbeda memenuhi persyaratan SNI mutu kerupuk amplang ikan.

\section{Kadar abu}

Berdasarkan Tabel 5 diketahui bahwa nilai rata-rata kadar abu kerupuk amplang ikan dengan penggunaan jenis ikan air tawar berbeda yaitu $3,10 \% \quad-3,97 \%$. Dimana perlakuan $A_{1}$ memiliki nilai terendah $(3,10 \%)$ sedangkan perlakuan $A_{2}$ memiliki nilai tertinggi $(3,97 \%)$. Hasil dari analisis variansi didapat bahwa perlakuan dengan penggunaan jenis ikan air tawar berbeda berpengaruh nyata terhadap nilai kadar abu kerupuk amplang ikan, dimana $F_{\text {Hitung }}(36,76)$ $>F_{\text {Tabel }}(5,14)$ pada tingkat kepercayaan $95 \%$ maka hipotesis $\left(\mathrm{H}_{0}\right)$ ditolak.

Berdasarkan hasil uji lanjut beda nyata jujur (BNJ) menunjukkan bahwa perlakuan $A_{1}$ tidak berbeda nyata terhadap perlakuan $A_{3}$, tetapi perlakuan $A_{1}$ dan $A_{3}$ berbeda nyata terhadap perlakuan $\mathrm{A}_{2}$ pada tingkat kepercayaan 95\%.

Kadar abu mengambarkan secara kasar kandungan bahan mineral dalam suatu bahan pangan yang biasanya komponen-komponen tersebut berupa magnesium, kalsium, besi dan mangan (Novianti et al. 2019).
Kandungan kadar mineral pada daging ikan dipengaruhi oleh habitat ikan tersebut.

Kadar abu yang dihasilkan dari kerupuk amplang ikan dengan penggunaan jenis ikan air tawar berbeda masih berada dibawah persyaratan SNI (maks 5\%), sehingga dapat dikatakan bahwa kadar abu kerupuk amplang ikan dengan penggunaan jenis ikan air tawar berbeda memenuhi persyaratan SNI mutu kerupuk amplang ikan.

\section{Kadar protein}

Berdasarkan Tabel 5 diketahui bahwa nilai rata-rata kadar protein kerupuk amplang ikan dengan penggunaan jenis ikan air tawar berbeda yaitu 17,25\% - 27,97\%. Dimana perlakuan $\mathrm{A}_{1}$ memiliki nilai terendah $(17,25 \%)$ sedangkan perlakuan $\mathrm{A}_{3}$ memiliki nilai tertinggi $(27,97 \%)$. Hasil dari analisis variansi didapat bahwa perlakuan dengan penggunaan jenis ikan air tawar berbeda berpengaruh nyata terhadap nilai kadar protein kerupuk amplang ikan, dimana $\mathrm{F}_{\text {Hitung }}$ $(76,68)>F_{\text {Tabel }}(5,14)$ pada tingkat kepercayaan $95 \%$ maka hipotesis $\left(\mathrm{H}_{0}\right)$ ditolak.

Berdasarkan hasil uji lanjut beda nyata jujur (BNJ) menunjukkan bahwa perlakuan $\mathrm{A}_{3}$ berbeda nyata terhadap perlakuan $\mathrm{A}_{2}$, dan perlakuan $\mathrm{A}_{2}$ berbeda nyata terhadap perlakuan $A_{1}$ pada tingkat kepercayaan 95\%. Kandungan protein amplang ikan akan dipengaruhi oleh kadar protein daging ikan yang digunakan dan nilai protein yang terukur akan semakin besar jika jumlah air yang hilang semakin besar.

Kadar protein kerupuk pasir ikan kembung lebih tinggi dari kerupuk udang pasir komersial dan terdapat perbedaan yang signifikan. Tingginya kadar protein pada kerupuk pasir ikan kembung disebabkan karna kadar protein yang terkandung dalam bahan baku ikan kembung (21,3\%) yang relatif lebih tinggi dari pada udang $(11,4 \%)$.

Hasil penelitian diketahui bahwa ratarata nilai kadar protein kerupuk amplang ikan dengan penggunaan jenis ikan air tawar berbeda yaitu berkisar antara 17,25-27,97\%. Kadar protein yang dihasilkan kerupuk amplang ikan memenuhi persyaratan SNI 
(min 7\%), sehingga dapat dikatakan bahwa kadar protein kerupuk amplang ikan dengan penggunaan jenis ikan air tawar berbeda memenuhi persyaratan SNI mutu kerupuk amplang ikan.

\section{Kadar lemak}

Berdasarkan Tabel 5 diketahui bahwa nilai rata-rata kadar lemak kerupuk amplang ikan dengan penggunaan jenis ikan air tawar berbeda yaitu 15,49\% - 24,32\%. Dimana perlakuan $\mathrm{A}_{3}$ memiliki nilai terendah $(15,49 \%)$ sedangkan perlakuan $A_{1}$ memiliki nilai tertinggi $(24,32 \%)$. Hasil dari analisis variansi didapat bahwa perlakuan dengan penggunaan jenis ikan air tawar berbeda berpengaruh nyata terhadap nilai kadar lemak kerupuk amplang ikan, dimana $\mathrm{F}_{\text {Hitung }}$ $(723,44)>F_{\text {Tabel }}(5,14)$ pada tingkat kepercayaan 95\% maka hipotesis $\left(\mathrm{H}_{0}\right)$ ditolak.

Berdasarkan hasil uji lanjut beda nyata jujur (BNJ) menunjukkan bahwa perlakuan $\mathrm{A}_{1}$ berbeda nyata terhadap perlakuan $\mathrm{A}_{2}$, dan perlakuan $\mathrm{A}_{2}$ berbeda nyata terhadap perlakuan A3 pada tingkat kepercayaan 95\%. Tinggi atau rendahnya kandungan lemak pada kerupuk amplang disebabkan oleh bahan yang digunakan dan daya serap terhadap minyak pada saat proses penggorengan.

Proses penggorengan mengakibatkan lemak pada minyak menyerap pada kerupuk amplang ikan yang digoreng. Penyerapan tersebut disebabkan oleh air yang ada pada kerupuk amplang ikan sebelum digoreng menguap pada proses penggorengan, dan mengakibatkan celah kosong akibat air yang menguap yang digantikan oleh minyak. Menurut Pokorny (1999) dalam Supriyadi (2012), ada beberapa faktor yang mempengaruhi masuknya minyak kedalam produk gorengan pada saat proses penggorengan yaitu suhu dan lama penggorengan, kadar air, khususnya di lapisan permukaan bahan, ukuran dan bentuk yang digoreng, perlakuan sebelum penggorengan, serta tipe dan kualitas minyak goreng yang digunakan.

Hasil penelitian diketahui bahwa ratarata nilai kadar lemak kerupuk amplang ikan dengan penggunaan jenis ikan air tawar berbeda yaitu berkisar antara 15,49-24,32\%. Kadar lemak yang dihasilkan kerupuk amplang ikan memenuhi persyaratan SNI (maks 35\%), sehingga dapat dikatakan bahwa kadar lemak kerupuk amplang ikan dengan penggunaan jenis ikan air tawar berbeda memenuhi persyaratan SNI mutu kerupuk amplang ikan.

\section{Uji Volume Pengembangan}

Hasil uji volume pengembangan kerupuk amplang ikan dengan penggunaan jenis ikan air tawar berbeda dapat dilihat pada Tabel 5.

Tabel 5. Nilai rata-rata volume pengembangan (\%) kerupuk amplang ikan dengan penggunaan jenis ikan air tawar berbeda

\begin{tabular}{cccc}
\hline \multirow{2}{*}{ Ulangan } & \multicolumn{3}{c}{ Perlakuan } \\
\cline { 2 - 4 } & $\mathrm{A} 1$ & $\mathrm{~A} 2$ & $\mathrm{~A} 3$ \\
\hline 1 & 80,35 & 207,27 & 468,07 \\
2 & 95,00 & 233,66 & 466,98 \\
3 & 89,50 & 219,20 & 453,42 \\
\hline Rata-rata & $88,28^{\mathrm{a}}$ & $220,04^{\mathrm{b}}$ & $462,82^{\mathrm{c}}$ \\
\hline
\end{tabular}

Keterangan : Angka-angka yang diikuti oleh notasi huruf yang berbeda berarti perlakuan berbeda nyata pada tingkat kepercayaan 95\%.

Berdasarkan Tabel 5 diketahui bahwa nilai rata-rata volume pengembangan kerupuk amplang ikan dengan penggunaan jenis ikan air tawar berbeda berturut-turut 88,28\%, 220,04\% dan 462,82\%. Dimana perlakuan $\mathrm{A}_{3}$ memiliki nilai tertinggi (462,82\%), sedangkan perlakuan $A_{1}$ memiliki nilai terendah $(88,28 \%)$. Hasil dari analisis variansi didapat bahwa perlakuan dengan penggunaan jenis ikan air tawar berbeda berpengaruh nyata terhadap nilai volume pengembangan kerupuk amplang ikan, dimana $\mathrm{F}_{\text {Hitung }}(1097,47)>\mathrm{F}_{\text {Tabel }}(5,14)$ pada tingkat kepercayaan 95\% maka hipotesis $\left(\mathrm{H}_{0}\right)$ ditolak.

Berdasarkan hasil uji lanjut beda nyata jujur (BNJ) menunjukkan bahwa perlakuan $\mathrm{A}_{3}$ berbeda nyata terhadap perlakuan $A_{2}$, serta perlakuan $\mathrm{A}_{2}$ berbeda nyata terhadap perlakuan $A_{1}$ pada tingkat kepercayaan $95 \%$. Hasil penelitian diketahui bahwa nilai volume pengembangan kerupuk amplang 
ikan dengan penggunaan jenis ikan air tawar berbeda yang terbaik adalah dengan penggunaan jenis ikan gabus $\left(\mathrm{A}_{3}\right)$ dimana nilai rata-rata volume pengembangan tertinggi yaitu $462,82 \%$.

Menurut penelitian Alfisyahrica (2015) mengenai bagian telur dan persentasenya dengan daging ikan pada proses pengolahan amplang ikan lele dumbo (Clarias gariepinus) menyatakan bahwa daya kembang tertinggi yaitu dengan penembahan bagian putih telur $(346,78 \%)$. Hal tersebut dikarenakan putih telur memiliki kandungan albumin sehingga dapat meningkatkan daya kembang akibat terbentuknya struktur yang lebih berongga daripada penggunaan bagian telur yang lain.

Menurut Supriatna et al. (1995) proses pengembangan suatu produk dipengaruhi oleh adanya granula pati yang tergelatinisasi. Granula pati yang tidak tergelatinisasi secara sempurna diakibatkan oleh adanya lemak yang ada pada produk tersebut. Kadar lemak dalam pati dan tepung dapat mengganggu proses gelatinisasi karena lemak mampu membentuk kompleks dengan amilosa, sehingga dapat menghambat keluarnya amilosa dari granula pati. Selain itu, sebagian besar lemak akan diabsorbsi oleh permukaan granula, sehingga berbentuk lapisan lemak yang bersifat hidrofobik di sekeliling granula. Lapisan lemak tersebut akan menghambat pengikatan air oleh granula pati. Hal ini menyebabkan kekentalan dan kelekatan pati berkurang akibat jumlah air berkurang untuk terjadinya pengembangan granula pati (Cillison 1998 dalam Siswanti et al. 2009).

Sejalan dengan penelitian Harsono (2006) mengenai pengaruh perbandingan daging ikan lele dengan tepung tapioka terhadap mutu kerupuk ikan yang dihasilkan menyatakan bahwa, volume pengembangan kerupuk sangat dipengaruhi oleh kandungan lemak yang terdapat pada ikan, semakin tinggi kandungan lemak maka semakin rendah volume pengembangan kerupuk.

\section{KESIMPULAN}

Berdasarkan hasil penelitian yang telah dilakukan, maka dapat disimpulkan bahwa pembuatan kerupuk amplang dengan penggunaan jenis ikan air tawar berbeda memberikan pengaruh yang nyata terhadap nilai organoleptik (rupa, aroma, tekstur dan rasa), analisis proksimat (kadar air, kadar abu, kadar protein dan kadar lemak) dan uji volume pengembangan pada tingkat kepercayaan 95\%.

Berdasarkan nilai organoleptik, perlakuan terbaik adalah perlakuan dengan penggunaan jenis ikan gabus $\left(\mathrm{A}_{3}\right)$ meliputi rupa (warna cerah merata spesifik produk, bersih), aroma (kuat spesifik produk), tekstur (renyah, berongga) dan rasa (cukup kuat spesifik ikan). Berdasarkan nilai proksimat yang terbaik yaitu perlakuan penggunaan jenis ikan gabus ( $\left.\mathrm{A}_{3}\right)$ meliputi kadar air 1,69\%, kadar abu 3,45\%, kadar protein 27,97\%, dan kadar lemak 15,49\%, serta volume pengembangan yang terbaik yaitu perlakuan $A_{3}$ memiliki nilai 462,82\%.

\section{DAFTAR PUSTAKA}

[BSN] Badan Standarisasi Nasional. 2013. Standar Nasional Indonesia. Amplang Ikan. SNI 7762:2013. Badan Standarisasi Nasional. Jakarta.

Alfisyahrica. 2015. Variasi Bagian Telur dan Persentasenya Dengan Daging Ikan Pada Proses Pengolahan Amplang Ikan Lele Dumbo (Clarias gariepinus). [Skripsi]. Jurusan Teknologi Hasil Pertanian. Fakultas Teknologi Pertanian. Universitas Jember.

Dewita dan Syahrul. 2014. Fortifikasi konsentrat protein ikan patin siam pada produk snack amplang dan mi sagu instan sebagai produk unggulan daerah riau. Jurnal Pengolahan Hasil Perikanan Indonesia. 17 (2): 156-164.

Harsono W. 2006. Pengaruh perbandingan daging ikan lele dengan tepung tapioka terhadap mutu kerupuk ikan yang dihasilkan [Skripsi]. Jurusan Budidaya Perairan. Universitas Jambi.

Laiya N, Rita MH, Nikmawatisusanti Y. 2014. Formulasi Kerupuk Ikan Gabus Yang Disubtitusi Dengan Tepung Sagu. Jurnal 
ilmiah perikanan dan kelautan. 2 (2): 8187.

Nofitasari N. 2015. Pengaruh Penggunaan Jenis Ikan Yang Berbeda Terhadap Kualitas Pempek. [Skripsi]. Universitas Negeri Padang.

Novianti, Elma, Suparmi, Desmelati. 2019. Studi Formulasi Pempek Ikan Jelawat (Leptobarbus haovenii) Dengan Penambahan Tepung Sagu Berbeda Terhadap Penerimaan Konsumen. Jurnal Online Mahasiswa FAPERIKA.

Rabiyatul A. 2016. Perbedaan Kualitas Kerupuk Amplang yang Dihasilkan dari Berbagai Sumber Protein. [Skripsi]. Jurusan Ilmu Kesejahteraan Keluarga. Fakultas Periwisata dan Perhotelan. Universitas Negeri Padang.

Siswanti R, Baskoro KA, Godras JM. 2009. Karakterisasi Edible Film Komposit Dari Glukomanan Umbi Iles-Iles (Amorphopallus muelleri) dan Maizena. Biofarmasi. 7 (1) : 10-21.

Supriatna D, Basrah EA, Betty DSM, Otong S. 1995. Pengaruh Perbandingan Daging Ikan
Dengan Tapioca Dan Cara Pengeringan Terhadap Mutu Kerupuk Ikan Tongkol (Euthynnus affinis) Yang Dibuat Secara Teknologi Intermediet. Warta IHP. 12 (12) : 78-83.

Supriyadi D. 2012. Studi Pengaruh Rasio Amilosa-Amilopektin Dan Kadar Air Terhadap Kerenyahan Dan Kekerasan Model Produk Gorengan. [Skripsi] Fakultas Teknologi Pertanian, Institute Pertanian Bogor. Bogor.

Suseno SH, Suptijah P, Wahyuni DS. 2004. Pengaruh Penambahan Daging Lumat Ikan Nilem (Ostheochilus hasselti) Pada Pembuatan Simping Sebagai Makanan Cemilan. Buletin Teknologi Hasil Perikanan. 7 (1): 44-55.

Suwarsito. 2007. Pengaruh L-Karnitin Terhadap Kadar Lemak Daging Dan Komposisi Tubuh Ikan Patin (Pengasius hypopthalmus). Jurnal Perikanan. 9 (1) : 63-68.

Wiranti T. 2015. Pengaruh Proporsi Tapioka, Tepung Garut, dan Daging Ikan Patin Terhadap Sifat Organoleptik Kerupuk. Ejurnal Boga. 4 (1) : 28-36. 